\title{
Effects of corn silage inclusion in preweaning calf diets
}

\author{
S. I. Kehoe, ${ }^{1 *}$ K. A. Dill-McFarland, ${ }^{2}$ Jacob D. Breaker, ${ }^{3}$ and G. Suen ${ }^{3}$ \\ ${ }^{1}$ Department of Animal and Food Science, University of Wisconsin-River Falls, River Falls 54022 \\ ${ }^{2}$ Department of Microbiology and Immunology, University of British Columbia, 2350 Health Sciences Mall, Vancouver, BC, V6T 1Z3, Canada \\ ${ }^{3}$ Department of Bacteriology, University of Wisconsin-Madison, Madison 53715
}

\section{ABSTRACT}

The objective of this research was to evaluate the effects of corn silage inclusion in starter feed provided to calves after birth through weaning at 7 wk of age. Thirty-six heifer calves and 9 bull calves were individually housed in hutches. Calves in treatment groups received pasteurized milk with all calf starter, $25 \%$ calf starter and $75 \%$ corn silage, or all corn silage. Values were recorded daily for feed intake and health, which included fecal, respiratory, and attitude scores; and at wk 2, 4, and 8 for concentrations of serum protein, hematocrit, and serum $\beta$-hydroxybutyrate. Body weight, withers height, and hip height were measured at wk 2, 4, 8, and 52 . Nine bull calves ( $3 /$ treatment) were killed at 8 wk of age for assessment of rumen and intestinal tissue morphology. Feed intake and average daily gain were not different among treatments. Least squares means of rumen papillae lengths were significantly different and decreased as corn silage inclusion increased. Crypt depths and total thickness of epithelium were reduced for the corn silage group. Least squares means of body weight, heart girth, hip height, withers height, serum protein, hematocrit, and $\beta$-hydroxybutyrate concentrations did not differ among treatments. These data indicated that the mixture of corn silage and starter did not affect growth, feed intake, or intestinal morphology but did affect rumen wall morphology. Feeding solely corn silage as starter feed stunted the growth of rumen papillae and tended to impair intestinal morphology, indicating that only calf starter or a mixture of calf starter and corn silage is more appropriate.

Key words: dairy calf, corn silage, rumen, intestine

\section{INTRODUCTION}

Rumen development is one of the priorities for raising replacement heifers to become healthy, productive

Received October 5, 2018.

Accepted January 9, 2019.

*Corresponding author: sylvia.kehoe@uwrf.edu lactating cows. However, young dairy calves provide no economic return; therefore, farmers search for cheaper nutritive alternatives to raise them. Although it has been well established that grains provide fermentation and rumen development needed in the calf (Flatt et al., 1958), multiple research teams have reported benefits of adding forage to preweaning calf diets (Khan et al., 2011; Montoro et al., 2013). Research results indicate that calves receiving a forage source, such as chopped grass hay, have increased total DMI and potentially better rumen development. However, the composition of calf starter used in some trials may have contributed to lower rumen $\mathrm{pH}$ and digestibility, which was then improved with the addition of hay or other forages.

According to the USDA census report, three-fourths of all dairy farms in the United States milked fewer than 100 cows in 2012 (USDA-NASS, 2012). Smaller farms that have less resources and labor may turn to using milking herd TMR or corn silage as a solid feed source for calves because of its easy on-farm availability and low cost. Compared with dry hay that may have a lower relative feed value, corn silage is shorter in particle length, is fermented for better digestibility, and provides moisture in the diet. Beiranvand et al. (2016) reported that the addition of water to dry calf starter, up to $50 \%$ moisture, led to increased total VFA production, DMI, and ADG.

Current results from a US survey show that $43 \%$ of farms provide forage to calves (Urie et al., 2018). The type of forage may not be as important; Terré et al. (2013) reported that rumen development is based more on NDF content than length of forage. Others have reported that calves consuming corn silage, instead of dry starter, have greater daily gains, increased protein digestibility, and increased final rumen mucosal weights (Suárez et al., 2007; Castells et al., 2012). Some of these studies mixed forage into starter (Coverdale et al, 2004; Suárez et al., 2007; Montoro et al., 2013) and some allowed free access to forage (Khan et al., 2011; Castells et al., 2012) as well as using different starter types, which may explain the different conclusions. Imani et al. (2017) conducted a meta-analysis of forage inclu- 
sion into preweaning calf diets and reported lower feed efficiency but an increase in starter intake, ADG, and final BW.

The objective of this research was to evaluate whether providing corn silage as part or in lieu of grain starter feed affects calf health, growth, and rumen and intestinal morphology.

\section{MATERIALS AND METHODS}

All experimental procedures were approved by University of Wisconsin-Madison Animal Care and Use Committee (protocol \#A01501).

\section{Animals, Housing, and Diet}

The trial used 45 Holstein heifer and bull calves born during summer and fall at the US Dairy Forage Research Center (Prairie Du Sac, WI). Calves were housed outside in individual plastic hutches $(1.8 \mathrm{~m} \times$ $1.37 \mathrm{~m}$ ) bedded with sand; straw was added in winter. All calves received $4 \mathrm{~L}$ of colostrum within $6 \mathrm{~h}$ of birth followed by 4 feedings of transition milk. Calves were fed $5.8 \mathrm{~L} / \mathrm{d}$ from 0 to $5 \mathrm{~d}$ and then $7.5 \mathrm{~L} / \mathrm{d}$ until 7 wk at weaning, when milk was gradually reduced. Pasteurized waste milk was fed with milk balancer protein blend (Land O'Lakes, St. Paul, MN) added to $15 \%$ total milk solids to provide an average of $3.2 \%$ milk protein and $3.7 \%$ milk fat. Water was offered daily ad libitum. Calves were monitored in individual pens from birth until 1 wk after weaning ( $8 \mathrm{wk}$ ). Corn silage, calf starter, and silage starter mix were collected monthly, subsampled, and submitted for nutrient analysis (Table 1) to Dairyland Laboratories, Inc. (Arcadia, WI).

Table 1. Formulated nutrient composition (DM basis) of calf starter, starter and corn silage mix, and corn silage treatments

\begin{tabular}{lrrr}
\hline & \multicolumn{3}{c}{ Treatment $^{2}$} \\
\cline { 2 - 4 } Item $^{1}$ & \multicolumn{1}{c}{$\mathrm{C}$} & \multicolumn{1}{c}{ SS } & \multicolumn{1}{c}{ CS } \\
\hline DM (\%) & 86.72 & 71.44 & 36.64 \\
CP (\%) & 24.94 & 20.76 & 7.52 \\
ADF (\%) & 8.38 & 10.73 & 23.34 \\
NDF (\%) & 21.34 & 18.90 & 34.42 \\
Ash (\%) & 6.97 & 6.54 & 4.04 \\
Lignin (\%) & 2.88 & 2.19 & 3.06 \\
NDFD 30 (\% of NDF) & 65.29 & 51.16 & 56.71 \\
Protein Sol. (\% of CP) & 9.55 & 24.37 & 57.18 \\
Starch (\%) & - & 38.27 & 34.44 \\
TDN (\%) & 78.95 & 76.63 & 69.09 \\
NFC (\%) & 52.31 & 51.68 & 51.04 \\
\hline
\end{tabular}

${ }^{1}$ NDFD $30=\mathrm{NDF}$ digestibility for $30 \mathrm{~h}$; Protein Sol. = protein solubility.

${ }^{2} \mathrm{C}=$ calf starter only; $\mathrm{SS}=50 \%$ calf starter and $50 \%$ corn silage mix; $\mathrm{CS}=$ corn silage only.
Calves were blocked by sex and date of birth to 1 of 3 treatments that began at $3 \mathrm{~d}$ of age: $100 \%$ calf starter (C; $58.25 \%$ whole corn, $1.75 \%$ molasses, and $40 \%$ Future Cow Ampli-Calf Mixer Pellet B150, Purina Animal Nutrition, Shoreview, MN), a mix of $50 \%$ calf starter and 50\% corn silage dry matter (SS), and $100 \%$ corn silage (CS). Calf starter and corn silage were weighed daily and mixed by hand. Nutrient analysis is shown in Table 1. Feed intake was measured daily until wk 7 and additional feed was added, if necessary. After $8 \mathrm{wk}$, calves received standard farm heifer rations through the last measurement at 52 wk of age.

\section{Blood, Health, and Growth Measurements}

Calves were weighed and measured for heart girth, hip height, and withers height $2 \mathrm{~d}$ after birth and at 2, 4 , and 8 wk of age. Additionally, heifers were weighed and measured once daily for $3 \mathrm{~d}$ during wk 52 of life to evaluate for any long-term weight or structural effects among treatments. Averages of these 3 consecutive measurements were used. One blood sample was taken at $48 \mathrm{~h}$ after birth for serum protein to determine status of passive transfer and at wk 2, 4, and 8, thereafter. Blood was collected at $4 \mathrm{~h}$ after the a.m. milk feeding from the jugular vein for hematocrit, serum protein, and BHB concentrations. Vacutainers (Becton, Dickinson and Co., Franklin Lakes, NJ) for hematocrit contained sodium heparin and those for total serum protein and BHB contained a clot enhancer. Samples were analyzed on the farm after collection for serum protein and hematocrit. Capillary tubes were spun for hematocrit values after which blood was centrifuged for $15 \mathrm{~min}$ at $3,600 \times \mathrm{g}$. Hematocrit was read using a Critocaps Micro-hematocrit Tube Reader (Thomas Scientific, Minneapolis, MN) and serum protein was read using an ocular refractometer (Nasco, Fort Atkinson, WI). The BHB samples from wk 2 and 8 were processed and frozen at $-20^{\circ} \mathrm{C}$ until further analysis at Marshfield Labs (Marshfield, WI). Health was recorded daily on each calf for scours (scale of 1-5, 1 being solid and 5 being very watery), respiration, and general appearance (Heinrichs et al., 2003). Fecal samples were obtained in wk 2 or 3 (to avoid sampling during scours) and wk 4, 8, and 52 for analysis of microbiota development for complementary research reported in DillMcFarland et al. (2017, 2019).

\section{Intestinal Sampling}

Nine bull calves ( $\mathrm{n}=3$ calves/treatment) were taken to the University of Wisconsin-Madison Meat Science Laboratory at 8 wk of age and slaughtered using cap- 
tive bolt gun and exsanguination. Immediately following exsanguination, the entire small and large intestine was removed from the body cavity. Within $5 \mathrm{~min}$, two 1-cm-long sections were rinsed in cold saline, cut from the jejunum (estimated midpoint), and placed in $10 \%$ formalin for morphometric analysis. The small intestine (duodenum, jejunum, ileum) was separated from the large intestine (cecum, colon, rectum) and both were measured in length and weighed.

\section{Intestinal Analyses}

For small intestinal morphology, jejunum tissue was embedded in paraffin blocks, sectioned at $9 \mu \mathrm{m}$, and stained with hematoxylin and eosin. Villus lengths and diameters and crypt depths of 20 villi were measured for each intestinal section using ImageJ (National Institutes for Health, Bethesda, MD), and means were calculated per segment for each calf. Only whole villuscrypt units were used for measurement, which included whole, rounded villus tips visibly connected to complete crypts that ended near the muscularis mucosal layer.

\section{Rumen Analyses}

After slaughter and exsanguination, rumens were emptied, washed, and frozen for later analysis at University of Wisconsin-River Falls. Four areas were identified for tissue collection based on Lesmeister et al. (2004). Three $1-\mathrm{cm}^{2}$ sections were collected from within each of the following 4 areas: left and right side caudal dorsal sacs and left and right side cranial ventral sacs. Using an optical binocular microscope (Olympus, Center Valley, PA), within each section, 10 random papillae were measured for length, width, and papillae concentration within a $1-\mathrm{cm}^{2}$ section. Each section was measured once for rumen wall thickness, and values were averaged for a mean within each section.

\section{Statistical Analysis}

Measurements were analyzed using a repeatedmeasures analysis of the mixed procedure of SAS (SAS Institute, 2013) with week as a repeated effect. Initial growth measurements were used as covariates for growth analysis. The statistical model used for analysis was

$$
\mathrm{Y}_{\mathrm{ijk}}=\mu+\mathrm{T}_{\mathrm{i}}+\mathrm{W}_{\mathrm{j}}+(\mathrm{TW})_{\mathrm{ij}}+\text { calf }_{\mathrm{k}}+\mathrm{e}_{\mathrm{ijk}},
$$

where $\mathrm{Y}_{\mathrm{ijk}}=$ dependent variable; $\mu=$ overall mean; $\mathrm{T}_{\mathrm{i}}$ $=$ fixed effect of treatment $\mathrm{i}$, where $\mathrm{i}=\mathrm{C}, \mathrm{SS}$, and CS; $\mathrm{W}_{\mathrm{j}}=$ repeated measure of week $\mathrm{j}$, where $\mathrm{j}=0,2,4,8$, or $52 \mathrm{wk} ;(\mathrm{TW})_{\mathrm{ij}}=$ effect of treatment $\times$ week interaction; calf $_{\mathrm{k}}=$ random effect of calf $\mathrm{k}$; and $\mathrm{e}_{\mathrm{ijk}}=$ residual.

Least squares means were determined using the general linear model of SAS (SAS Institute, 2013) for intestinal and ruminal measurements. The statistical model used for analysis was

$$
\mathrm{Y}_{\mathrm{ijk}}=\mu+\mathrm{T}_{\mathrm{i}}+\mathrm{D}_{\mathrm{j}}+(\mathrm{TD})_{\mathrm{ij}}+\text { calf }_{\mathrm{k}}+\mathrm{e}_{\mathrm{ijk}} \text {, }
$$

where $Y_{\mathrm{ijk}}=$ dependent variable; $\mu=$ overall mean; $T_{\mathrm{i}}$ = fixed effect of treatment $\mathrm{i}$, where $\mathrm{i}=\mathrm{C}, \mathrm{CS}$, and $\mathrm{SS}$; $\mathrm{D}_{\mathrm{j}}=$ fixed effect of day of slaughter $\mathrm{j}$; (TD $)_{\mathrm{ij}}=$ effect of treatment $\times$ day interaction; calf $_{\mathrm{k}}=$ random effect of calf $\mathrm{k}$; and $\mathrm{e}_{\mathrm{ijk}}=$ residual.

Least squares means were further evaluated if the model was significant at $P<0.05$ and trends were determined at $P<0.10$.

\section{RESULTS}

\section{Feed Intake and Growth Measurements}

Starter intake (Figure 1) over the entire treatment period of $7 \mathrm{wk}$ averaged 293, 348, and $245 \mathrm{~g} / \mathrm{d}$ for treatments $\mathrm{C}, \mathrm{SS}$, and $\mathrm{CS}$, respectively $(P=0.19)$. There was a significant week effect $(P<0.01)$, as expected, but treatments did not differ. Feed efficiency was not significant, as shown in Table 2.

Birth BW, heart girth, withers height, and hip height did not differ among treatments when recorded at d 2 . Weekly and final growth parameters did not differ $(P$ $>0.05$ ) for treatments C, SS, and CS over time (Table 2 ). Gut fill was not accounted for because only partial data were collected by mistake. The treatment $\times$ week interaction (see Table 2) for ADG was significant $(P$ $=0.045$ ): during wk 2 , treatment CS had significantly

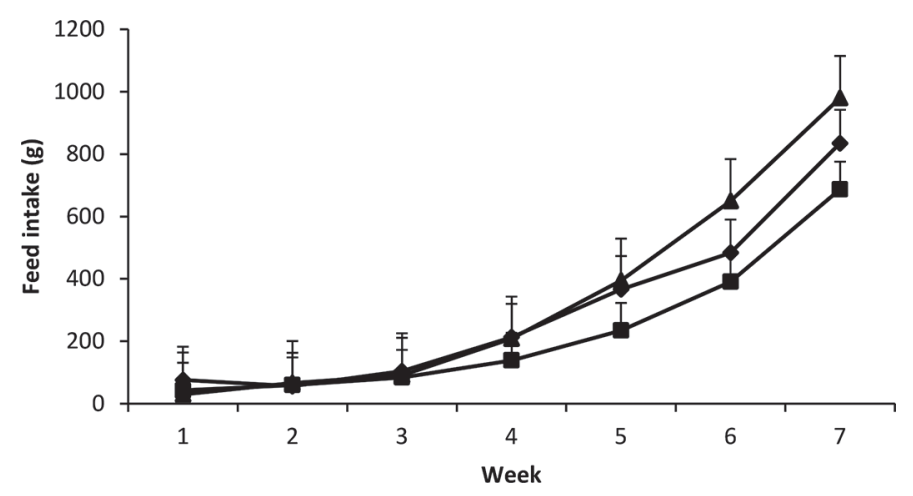

Figure 1. Least squares means (SE) of as-fed starter intake for treatments over time for calves fed whole milk and $100 \%$ calf starter $(\mathrm{C}, \boldsymbol{\diamond}), 50 \%$ calf starter and $50 \%$ corn silage mix (SS, $\boldsymbol{\Delta})$, or $100 \%$ corn silage (CS, $\mathbf{\square}$ ). 
Table 2. Least squares means of growth parameters and feed efficiency among calves fed calf starter, starter and corn silage mix, and corn silage

\begin{tabular}{|c|c|c|c|c|c|}
\hline \multirow[b]{2}{*}{ Variable } & \multicolumn{3}{|c|}{ Treatment $^{1}$} & \multirow[b]{2}{*}{ SEM } & \multirow[b]{2}{*}{$P$-value } \\
\hline & $\mathrm{C}$ & SS & CS & & \\
\hline \multicolumn{6}{|l|}{ BW (kg) } \\
\hline Day 2 & 45.22 & 43.44 & 44.86 & 1.32 & 0.605 \\
\hline Week 8 & 107.90 & 103.45 & 102.35 & 2.89 & 0.363 \\
\hline \multicolumn{6}{|l|}{$\mathrm{ADG}^{2}$} \\
\hline Week 0-8 & 0.909 & 0.998 & 0.876 & 0.053 & 0.255 \\
\hline Week 2 & $0.663^{\mathrm{b}}$ & $0.998^{\mathrm{a}}$ & $0.719^{\mathrm{b}}$ & 0.097 & 0.043 \\
\hline Week 4 & 0.948 & 0.889 & 0.859 & 0.078 & 0.718 \\
\hline Week 8 & 1.115 & 1.106 & 1.047 & 0.045 & 0.526 \\
\hline \multicolumn{6}{|l|}{ Structural $(\mathrm{cm})$} \\
\hline Heart girth & 97.51 & 96.91 & 96.94 & 0.37 & 0.451 \\
\hline Withers height & 83.05 & 82.23 & 82.58 & 0.29 & 0.155 \\
\hline Hip height & 88.28 & 88.59 & 88.40 & 0.31 & 0.774 \\
\hline \multicolumn{6}{|l|}{$\mathrm{FE}^{3}$} \\
\hline Week $0-8$ & 0.889 & 0.905 & 0.756 & 0.122 & 0.645 \\
\hline Week 2 & 0.322 & 0.203 & 0.362 & 0.124 & 0.644 \\
\hline Week 4 & 0.701 & 0.616 & 0.362 & 0.172 & 0.357 \\
\hline Week 8 & 1.644 & 1.895 & 1.545 & 0.268 & 0.639 \\
\hline
\end{tabular}

${ }^{\mathrm{a}, \mathrm{b}}$ Different superscripts within a row indicate differences $(P<0.05)$ among treatments.

${ }^{1} \mathrm{C}=$ calf starter only; $\mathrm{SS}=50 \%$ calf starter and $50 \%$ corn silage mix; CS = corn silage only.

${ }^{2} \mathrm{ADG}$ was calculated as kilograms of gain per time specified.

${ }^{3}$ Feed efficiency: kilograms of DMI per kilogram of gain.

greater ADG than treatments C and SS $(0.99 \mathrm{~kg} / \mathrm{d}$ vs. 0.66 and $0.72 \mathrm{~kg} / \mathrm{d}$, respectively).

Results of body measurements at 52 wk of age did not differ among treatments $(P>0.05)$. Body weight was $380.56,386.53$, and $374.67 \mathrm{~kg}$ for C, SS, and CS treatments, respectively. Withers height was 126.46 , 126.54 , and $126.71 \mathrm{~cm}$, and hip height averaged 131.33, 131.88 , and $131.04 \mathrm{~cm}$ for C, SS, and CS, respectively.

\section{Blood Parameters}

Least squares means of hematocrit, serum protein, and BHB are presented in Table 3. Hematocrit values were $62.99,62.80$, and $64.36 \%$ for $\mathrm{C}, \mathrm{SS}$, and CS, respectively $(P=0.636)$. Concentrations of serum protein were $6.75,6.69$, and $6.76 \mathrm{mg} / \mathrm{dL}(P=0.873)$, and those of BHB were $1.55,1.39$, and $1.41 \mathrm{mg} / \mathrm{dL}$ for $\mathrm{C}$, SS, and CS, respectively $(P=0.732)$. We detected a week effect such that BHB concentration increased with age; however, there was no treatment $\times$ week interaction.

\section{Health Parameters}

Least squares means of fecal scores were 2.33, 2.25, and $2.35(P=0.32)$, and attitude scores were 1.04 , 1.05 , and $1.03(P=0.47)$ for $\mathrm{C}, \mathrm{SS}$, and CS treatments, respectively. Least squares means of respiratory scores were $1.23,1.45$, and CS were $1.32(P=0.22)$ for $\mathrm{C}$, SS, and CS treatments, respectively. Milk refusals and treatments were not significantly different.

Table 3. Least squares means of blood parameters among calves fed calf starter, starter and corn silage mix, and corn silage

\begin{tabular}{|c|c|c|c|c|c|}
\hline \multirow[b]{2}{*}{ Variable } & \multicolumn{3}{|c|}{ Treatment $^{1}$} & \multirow[b]{2}{*}{ SEM } & \multirow[b]{2}{*}{$P$-value } \\
\hline & $\mathrm{C}$ & SS & CS & & \\
\hline Hematocrit (\%) & 62.99 & 62.80 & 64.36 & 1.25 & 0.636 \\
\hline Serum protein $(\mathrm{mg} / \mathrm{dL})$ & 6.75 & 6.69 & 6.76 & 0.09 & 0.873 \\
\hline \multicolumn{6}{|l|}{$\mathrm{BHB}(\mathrm{mg} / \mathrm{dL})$} \\
\hline Week 2 & 0.85 & 0.79 & 0.74 & 0.06 & 0.443 \\
\hline Week 8 & 2.26 & 1.99 & 2.07 & 0.31 & 0.826 \\
\hline Overall & 1.55 & 1.39 & 1.41 & 0.16 & 0.732 \\
\hline
\end{tabular}

${ }^{1} \mathrm{C}=$ calf starter only; $\mathrm{SS}=50 \%$ calf starter and $50 \%$ corn silage mix; CS $=$ corn silage only. 
Table 4. Least squares means of rumen variables among calves fed calf starter, starter and corn silage mix, and corn silage

\begin{tabular}{|c|c|c|c|c|c|}
\hline \multirow[b]{2}{*}{ Variable $^{1}$} & \multicolumn{3}{|c|}{ Treatment $^{2}$} & \multirow[b]{2}{*}{ SEM } & \multirow[b]{2}{*}{$P$-value } \\
\hline & $\mathrm{C}$ & SS & CS & & \\
\hline Papillae length (mm) & $9.32^{\mathrm{a}}$ & $7.53^{\mathrm{b}}$ & $3.92^{\mathrm{c}}$ & 0.31 & $<0.0001$ \\
\hline Papillae width (mm) & $2.93^{\mathrm{a}}$ & $2.49^{\mathrm{b}}$ & $1.46^{\mathrm{c}}$ & 0.13 & $<0.0001$ \\
\hline Papillae concentration ${ }^{3}$ & $42.25^{\mathrm{a}}$ & $50.21^{\mathrm{b}}$ & $48.68^{\mathrm{b}}$ & 2.23 & 0.025 \\
\hline Rumen wall thickness (mm) & 5.39 & 5.79 & 5.39 & 0.35 & 0.662 \\
\hline
\end{tabular}

${ }^{\mathrm{a}-\mathrm{c}}$ Means with different superscripts within row indicate differences $(P<0.05)$ among treatments.

${ }^{1}$ Mean of papillae values.

${ }^{2} \mathrm{C}=$ calf starter only; $\mathrm{SS}=50 \%$ calf starter and $50 \%$ corn silage mix; $\mathrm{CS}=$ corn silage only.

${ }^{3}$ Number of papillae in a $1-\mathrm{cm}^{2}$ section.

\section{Rumen Morphology}

Calves fed calf starter had longer rumen papillae $(P$ $<0.05)$, wider rumen papillae $(P<0.05)$, and lower papillae density in a $1-\mathrm{cm}^{2}$ area $(P=0.025)$ compared with other treatments (Table 4). In contrast, CS calves had significantly shorter and thinner papillae $(P<$ $0.05)$ but similar papillae density as the SS treatment. Rumen wall thickness did not differ among treatments $(P=0.662)$.

\section{Intestinal Morphology}

Calves fed corn silage had the shortest intestinal crypts $(P=0.02$; Table 5$)$. Additionally, total villus length plus crypt depth was significantly shorter for CS calves than for calves in the other treatments $(P=$ $0.03)$.

\section{DISCUSSION}

In the current study, calves fed only calf starter had increased rumen papillae length and width. We showed a linear reduction in papillae length and width as the amount of corn silage in the diet increased. Calves fed only calf starter had the lowest density of rumen papillae, most likely because they also had the longest and widest papillae of all treatments. Castells et al. (2013) also reported a linear decrease in papillae length for calves fed forage sources compared with calf starter only. We found no differences in BHB concentrations, indicating that although the rumen structure was physically different among treatments, this may not have affected butyrate production and utilization in the rumen. Intestinal parameters showed no differences between calves fed calf starter only and those fed a mixture of calf starter and corn silage, indicating that both diets may be fed without reducing the intestinal surface area. Calves fed only corn silage had reduced intestinal morphology and rumen papillae when slaughtered at 8 wk. This may be explained by the low protein content of the corn silage, which has previously been reported to reduce intestinal villus lengths and crypt depths (Peng et al., 2016).

Feeding calf starter or calf starter mixed with corn silage did show differences in ADG by the second week of life, when the calves fed the starter-corn silage mix gained significantly more than the other groups. However, this difference did not last and, overall, we observed no other differences in feed intake or growth parameters, even through 1 yr of life. However, during the trial, we were unable to account for gut fill in the slaughtered bull calves. Potentially, calves that consumed any level of forage may have had greater gut

Table 5. Least squares means of intestinal variables among calves fed calf starter, starter and corn silage mix, and corn silage

\begin{tabular}{|c|c|c|c|c|c|}
\hline \multirow[b]{2}{*}{ Variable } & \multicolumn{3}{|c|}{ Treatment $^{1}$} & \multirow[b]{2}{*}{ SEM } & \multirow[b]{2}{*}{$P$-value } \\
\hline & $\mathrm{C}$ & SS & CS & & \\
\hline Villus length $(\mu \mathrm{m})$ & 97.65 & 105.61 & 89.57 & 5.81 & 0.1242 \\
\hline Villus width $(\mu \mathrm{m})$ & 14.51 & 15.38 & 17.17 & 2.34 & 0.6927 \\
\hline Crypt depth $(\mu \mathrm{m})$ & $46.10^{\mathrm{a}}$ & $48.58^{\mathrm{a}}$ & $38.69^{\mathrm{b}}$ & 2.83 & 0.0269 \\
\hline $\operatorname{Total}^{2}(\mu \mathrm{m})$ & $144.02^{\mathrm{a}}$ & $154.81^{\mathrm{a}}$ & $128.46^{\mathrm{b}}$ & 7.52 & 0.0349 \\
\hline
\end{tabular}

${ }^{\mathrm{a}, \mathrm{b}}$ Means with different superscripts within row indicate differences $(P<0.05)$ among treatments.

${ }^{1} \mathrm{C}=$ calf starter only; $\mathrm{SS}=50 \%$ calf starter and $50 \%$ corn silage mix; $\mathrm{CS}=$ corn silage only.

${ }^{2}$ Total $=$ villus length plus crypt depth. 
fill, which could have camouflaged the lack of differences among treatments on BW and gain. However, the amount of calf starter consumed and rumen wall thickness was not different among treatments, indicating that forage may not have had this effect.

The fact that the starter was texturized and the corn silage was good quality may have been sufficient to reduce any significant differences among treatments. Other research studies showing improvements in calf performance with added forage typically fed a pelleted starter (Coverdale et al., 2004; Castells et al., 2013; Montoro et al., 2013; Terré et al., 2013). The texturized starter in our trial may have fermented more slowly in the rumen, causing forage to have less of an effect on the rumen environment. Mirzaei et al. (2017) reported increased feed intake, rumen VFA profile, ADG, and final $\mathrm{BW}$ for calves fed a mixture of corn silage and texturized calf starter. The difference in results may be due to the level of corn silage inclusion, which was $50 \%$ DM for this trial and 15\% for Mirzaei et al. (2017).

Multiple researchers have found few differences among calves fed only calf starter compared with those fed forage mixtures. Suárez et al. (2007) found few differences between calves fed grain starter or corn silage except for thicker rumen mucosa in corn silage-fed calves. Suarez-Mena et al. (2016) reported few differences in rumen fermentation and none in rumen development for calves fed starter with $5 \%$ straw inclusion. The lack of differences in previous research supports the current research findings that indicate a mixture of corn silage with calf starter results in few differences compared with calf starter only. Mollenhorst et al. (2016) reported economic benefits of providing a calf starter forage mixture to veal calves; producers may want to investigate this further as a means to reduce calf-rearing costs.

\section{CONCLUSIONS}

Overall, calves fed corn silage had reduced rumen and intestinal measurements, which might indicate a reduction of efficiency in nutrient utilization in the future. Calves fed only calf starter had more surface area due to longer and wider rumen papillae compared with calves on the other treatments. Calves fed a mixture of calf starter and corn silage had longer and wider rumen papillae than calves fed only corn silage. Calves fed only starter or a mixture of starter and corn silage had similar crypt depths and total villi and crypt depths compared with calves fed only corn silage. For final data collection at $8 \mathrm{wk}$, results indicated no significant differences in growth, gain, or health of calves fed any of these diets; however, calves fed only corn silage had reduced rumen papillae and intestinal measurements, indicating potential for future problems. A producer looking to reduce costs of calf care may investigate the possibility of introducing some corn silage (50\% of DM diet) to the calf diet without any detrimental effects.

\section{ACKNOWLEDGMENTS}

This work was supported by USDA National Institute of Food and Agriculture (Washington, DC) Hatch grant WIS01729 and foundational grant 2015-6701523246 to G. Suen. The authors thank Ron Skoyen and the staff at the US Dairy Forage Research Center (Madison, WI) for daily animal care. Thanks also go to Stacy Retz, Mikayla Dolan, Tawna Pogreba, and Jacob McLeod (who were all undergraduate students helping with this research at the University of WisconsinRiver Falls) for their hard work in rumen and intestinal sample preparation and measurement.

\section{REFERENCES}

Beiranvand, H., M. Khani, S. Omidian, M. Ariana, R. Rezvani, and M. H. Ghaffari. 2016. Does adding water to dry calf starter improve performance during summer? J. Dairy Sci. 99:1903-1911. https:// doi.org/10.3168/jds.2015-10004.

Castells, L., A. Bach, A. Arid, and M. Terré. 2013. Effects of forage provision to young calves on rumen fermentation and development of the gastrointestinal tract. J. Dairy Sci. 96:5226-5236. https:// doi.org/10.3168/jds.2012-6419.

Castells, L., A. Bach, G. Araujo, C. Montorro, and M. Terré. 2012. Effect of different forage sources on performance and feeding behavior of Holstein calves. J. Dairy Sci. 95:286-293. https://doi .org/10.3168/jds.2011-4405.

Coverdale, J. A., H. D. Tyler, J. D. Quigley III, and J. A. Brumm. 2004. Effect of various levels of forage and form of diet on rumen development and growth in calves. J. Dairy Sci. 87:2554-2562.

Dill-McFarland, K. A., J. D. Breaker, and G. Suen. 2017. Microbial succession in the gastrointestinal tract of dairy cows from 2 weeks to first lactation. Sci. Rep. 7:40864. https://doi.org/10.1038/ srep40864.

Dill-McFarland, K. A., P. J. Weimer, J. D. Breaker, and G. Suen. 2019. Diet influences early microbiota development in dairy calves without long-term impacts on milk production. Appl. Environ. Microbiol. 85:e02141-18. https://doi.org/10.1128/AEM.02141-18.

Flatt, W. P., R. G. Warner, and J. K. Loosli. 1958. Influence of purified materials on the development of the ruminant stomach. J. Dairy Sci. 41:1593-1600. https://doi.org/10.3168/jds.S0022 $-0302(58) 91138-\mathrm{X}$.

Heinrichs, A. J., C. M. Jones, and B. S. Heinrichs. 2003. Effects of mannan oligosaccharides or antibiotics in neonatal diets on health and growth of calves. J. Dairy Sci. 86:4064-4069.

Imani, M., M. Mirzaei, B. Baghbanzadeh-Nobari, and M. H. Ghaffari. 2017. Effect of forage provision to dairy calves on growth performance and rumen fermentation: A meta-analysis and metaregression. J. Dairy Sci. 100:1136-1150. https://doi.org/10.3168/ jds.2016-11561.

Khan, M. A., D. M. Weary, and M. A. G. von Keyserlingk. 2011. Hay intake improves performance and rumen development of calves fed higher quantities of milk. J. Dairy Sci. 94:3547-3553. https://doi .org/10.3168/jds.2010-3871.

Lesmeister, K. E., P. R. Tozer, and A. J. Heinrichs. 2004. Development and analysis of a rumen tissue sampling procedure. J. Dairy Sci. 
87:1336-1344. https://doi.org/10.3168/jds.S0022-0302(04)73283 $-\mathrm{X}$.

Mirzaei, M., M. Khorvash, G. R. Ghorbani, M. Kazemi-Bonchenari, and M. H. Ghaffari. 2017. Growth performance, feeding behavior, and selected blood metabolites of Holstein dairy calves fed restricted amounts of milk: No interactions between sources of finely ground grain and forage provision. J. Dairy Sci. 100:1086-1094. https://doi.org/10.3168/jds.2016-11592.

Mollenhorst, H., P. B. Berentsen, H. Berends, W. J. Gerrits, and I. J. de Boer. 2016. Economic and environmental effects of providing increased amounts of solid feed to veal calves. J. Dairy Sci. 99:2180-2189. https://doi.org/10.3168/jds.2014-9212.

Montoro, C., E. K. Miller-Cushon, T. J. DeVries, and A. Bach. 2013. Effect of physical form of forage on performance, feeding behavior, and digestibility of Holstein calves. J. Dairy Sci. 96:1117-1124. https://doi.org/10.3168/jds.2012-5731.

Peng, X., L. Hu, Y. Liu, C. Yan, Z. F. Fang, Y. Lin, S. Y. Xu, J. Li, C. M. Wu, D. W. Chen, H. Sun, D. Wu, and L. Q. Che. 2016. Effects of low-protein diets supplemented with indispensable amino acids on growth performance, intestinal morphology and immunological parameters in 13 to $35 \mathrm{~kg}$ pigs. Animal 10:1812-1820. https://doi .org/10.1017/S1751731116000999.
SAS Institute. 2013. SAS Version 9.4. SAS Institute Inc., Cary, NC. Suárez, B. J., C. G. Van Reenen, N. Stockhofe, J. Dijkstra, and W. J. Gerrits. 2007. Effect of roughage source and roughage to concentrate ratio on animal performance and rumen development in veal calves. J. Dairy Sci. 90:2390-2403. https://doi.org/10.3168/ jds.2006-524.

Suarez-Mena, F. X., A. J. Heinrichs, C. M. Jones, T. M. Hill, and J. D. Quigley. 2016. Straw particle size in calf starters: Effects on digestive system development and rumen fermentation. J. Dairy Sci. 99:341-353. https://doi.org/10.3168/jds.2015-9884.

Terré, M., E. Pedrals, A. Dalmau, and A. Bach. 2013. What do preweaned and weaned calves need in the diet: A high fiber content or a forage source? J. Dairy Sci. 96:5217-5225. https://doi.org/10 .3168/jds.2012-6304.

Urie, N. J., J. E. Lombard, C. B. Shivley, C. A. Kopral, A. E. Adams, T. J. Earlywine, J. D. Olson, and F. B. Garry. 2018. Preweaned heifer management on US dairy operations: Part I. Descriptive characteristics of preweaned heifer raising practice. J. Dairy Sci. 101:9168-9184. https://doi.org/10.3168/jds.2017-14010.

USDA-NASS (National Agricultural Statistics Service). 2012 Census of Agriculture. https://www.nass.usda.gov/Publications/AgCensus/ 2012/index.php\#highlights. 